\title{
ASSESSMENT OF DECIDUOUS TREES STATE AND PHYLLOPHAGOUS COMPOSITION IN YOSHKAR-OLA
}

\section{(C) 2017}

Turmuhametova Nina Valeryevna, candidate of biological sciences, associate professor of Biology Department Mari State University (Yoshkar-Ola, Russian Federation)

Abstract. This paper presents the results of long-term observations of the state of plantations of Betula pendula Roth and Tilia cordata Mill. in Yoshkar-Ola. Assessment of trees state was carried out by morphological analysis of the leaf blade, since the plant's assimilation organs are most exposed to atmospheric toxicants, attacks of insects and pathogenic microorganisms. Based on the assumption that pollutants affect directly phytophages or through the forage resource, the species composition of the phyllophagous insects and mites was studied in the gradient of the increase in industrial transport emissions. Morphological changes in leaves and an increase in the area of damage in the pollution gradient are described. In this case, the area of the leaf blade can both increase in B. pendula, and decrease in $T$. cordata. Determination of the arachnoentomological material and the establishment of herbivorous insects and mites for characteristic lesions made it possible to describe in the crowns of B. pendula 84 dendrobiotic species, T. cordata -100 species. Among the phyllophagous there are gnawing and sucking leaves, miners and gall producers. The representatives of Coleoptera predominate. Under environmental conditions, the proportion of arthropods that are monophages and form protective devices increases. Under the conditions of the urban ecosystem, a decrease in the variety of phyllophages was revealed, but an increase in the relative abundance of the most protected species Aphidoidae (Homoptera), Cecidomyiidae (Diptera), Eriophyidae (Acarina). The calculation of the number of insects per unit volume of the crown was carried out. As a bioindicative indicator of the quality of habitat, it is suggested to use the state of tree leaves, the diversity and relative abundance of insects and mites of phyllophages.

Keywords: Betula pendula; Tilia cordata; bioindication; biomonitoring; quality of environment; pollution of environment; ontogenetic state; leaf blade; damage; phylophagous; arthropods; mites; insects; Coleoptera; monophages; relative abundance; number; Yoshkar-Ola; Mari El Republic.

УДК 581.9

Статья поступила в редакцию 12.10.2017

\section{СТРУКТУРА ЭКОЛОГИЧЕСКОГО КАРКАСА БАССЕЙНА РЕКИ СВИЯГИ}

(C) 2017

Фролов Даниил Анатольевич, кандидат биологических наук, доцент кафедры биологии и химии Ульяновский государственный педагогический университет имени И.Н. Ульянова

(2. Ульяновск, Российская Федераичи)

Аннотация. В представленной статье рассматривается авторский экологический каркас бассейна реки Свияги (правого притока реки Волги), созданный на основе многолетнего изучения флоры сосудистых растений естественного выдела природы, расположенного в центральной части Приволжской возвышенности. Дается флористическое и геоботаническое описание ключевых участков - ядер в структуре каркаса речного бассейна, с обоснованием причин их выделения и приведением раритетных видов сосудистых растений флоры бассейна, придающих значимость территории исследования. Приводятся краткие сведения о коридорах и буферных зонах в структуре экологического каркаса, представляющие собой непрерывные линейные структуры и служащие своеобразными мостами для миграции биологических видов между ядрами каркаса. Помимо ядер, коридоров и буферных зон в бассейне р. Свияги были выделены перспективные участки (в количестве 7) - резерваты редких и охраняемых видов растений. Приводятся сведения о существующей системе особо охраняемых территорий объекта исследования и перспективных участках, рекомендованных к включению в сеть существующих ООПТ Ульяновской области и республики Татарстан, для сохранения флористического разнообразия региона. Представленный экологический каркас создаст хорошие предпосылки для сохранения биоразнообразия региона и способствует поддержанию природного потенциала бассейна реки Свияги.

Ключевые слова: экологический каркас; бассейн реки; река Свияга; ядро; коридор; буферная зона; флора; растительность; особо охраняемые природные территории (ООПТ); видовое разнообразие; биоразнообразие; Красная книга; памятник природы; охотничий заказник; Ульяновская область; Республика Татарстан.

\section{Введение}

Поддержание экологического равновесия любой природной экосистемы основано на её способности к самовосстановлению. Однако в условиях усиливающегося антропогенного прессинга такие способности не безграничны. В связи с этим важнейшей природоохранной задачей становится предотвращение деградации экосистем выше допустимого уровня. Одним из ведущих методических приемов определения экологического потенциала территории является кон- цепция экологического каркаса, под которым в общем случае понимается система наиболее ценных по своим природным характеристикам участков территории. Вслед за Н.Ф. Реймерсом [1], мы рассматриваем экологический каркас как систему ранжированных по степени экологического значения, переходящих друг в друга природных участков - «ядер», «коридоров», «буферных зон», неразрывно связанных друг с другом. При этом функционирование взаимосвязей между ними - главное условие поддержания 
естественного экологического равновесия территории, выполнение ими средообразующих функций.

В качестве объекта исследования был выбран бассейн р. Свияги, как типичный природный выдел, расположенный в зоне активного антропогенного воздействия на экосистемы Приволжской возвышенности. Административно территория бассейна принадлежит 2 субъектам Российской Федерации - Ульяновской области и Республике Татарстан.

\section{Методика исследования}

В пределах бассейна на основании имеющихся материалов [2-14] и данных собственных флористических исследований [15-22] были выделены по общепринятым методикам участки, выполняющие функции ядер, или зон экологической стабилизации [23]. В их состав включены как уже существующие ООПТ (в основном региональные памятники природы и заказники), так и перспективные участки, выделенные в ходе собственных флористических исследований и необходимые для эффективной охраны флоры в рамках создаваемого экологического каркаса бассейна Свияги.

\section{Результаты исследования и их обсуждение}

Ядро № 1. Расположено в верховьях р. Свияги на территории Кузоватовского района Ульяновской области. Ядро представлено двумя участками - истоком р. Свияги и озером Зотово с прилегающими территориями. Собственно указанные участки являются сосредоточием флористического и ценотического разнообразия верхней части бассейна.

Исток Свияги, памятник природы, расположен в 5 км к юго-западу от села Кузоватово (Ульяновская область), на возвышенности, занятой высокоствольным сосняком.

Роль участка в составе ядра объясняется ландшафтной целостностью истока и прилегающих к нему территорий, сохранностью эталонных сосновых лесов-зеленомошников, присутствием во флоре реликтовых (Festuca altissima, Vaccinium myrtillus, V. vitis-idaea), охраняемых (Neottinanthe cucullata, Phegopteris connectilis, Pyrola minor) и редких (Calla palustris, Cystopteris fragilis, Gymnocarpium dryopteris, Hypopitys monotropa, Neottia nidus-avis, Platanthera bifolia, Pyrola rotundifolia, Pyrola chlorantha, Viola montana, Primula veris) видов растений, в том числе новых для Ульяновской области флористических находок - Alchemilia propinqua и Viola selkirkii.

Второй участок - природный памятник Озеро Зотово с прилегающими территориями - находится в 4,5 км северо-западнее с. Коромысловка. Территория включает в себя озеро, зарастающее прибрежноводной растительностью, окруженное коренными сосновыми и сосново-широколиственными лесами.

Значение озера в ядре объясняется его водоохранной ролью, сохранностью типичных луговых, прибрежно-водных и лесных сообществ, произрастанием редких (Platanthera bifolia, Pyrola rotundifolia, Pulsatilla patens) и охраняемых (Utricularia vulgaris) видов растений.

Ядро № 2. Находится в центральной части бассейна, включает преимущественно участки типичных луговых, болотных и прибрежно-водных ценозов. Центрами сохранения биологического и ланд- шафтного разнообразия ядра служат: природный комплекс экологический парк “Черное озеро», расположенный в г. Ульяновске, Брехово болото близ р.п. Ишеевка Ульяновского района и рябчиковый луг близ с. Арбузовка Цильнинского района.

«Черное озеро», памятник природы, - природный ландшафтный комплекс, расположенный в центре города Ульяновска, включает в себя пойменное старичное озеро - Черное, левобережный участок речной долины и акватории р. Свияги с островами.

Во флоре экопарка зарегистрировано более 430 видов сосудистых растений из 262 родов и 77 семейств, что составляет третью часть флористического разнообразия бассейна р. Свияги.

Значимость экопарку придают растения, относящиеся к категории охраняемых (Cypripedium calceolus, Listera ovata, Dactylorhiza fuchsii, Equisetum ramosissimum) и редких (Leersia oryzoides, Elymus fibrosus, Urticularia vulgaris).

Рябчиковый луг в окрестностях села Арбузовка (памятник природы). Сохранившийся участок расположен в 2 км восточнее с. Арбузовка Цильнинского района Ульяновской области в среднем течении p. Свияги.

Ценность луга заключается в хорошей сохранности луговых и прибрежно-водных сообществ; наличием на территории крупной популяции Fritillaria meleagroides; произрастанием редких видов растений (Artemisia abrotanum, Helictotrichon schellianum, Salix starkeana), в том числе нового для Ульяновской области вида - Ranunculus schennikovi.

Болото Брехово, памятник природы, расположено в левобережной пойме р. Свияги (среднее течение) в 1,5 км к западу от р.п. Ишеевка Ульяновского p-на Ульяновской области.

Среди причин, по которым болото Брехово включено в состав ядра экологического каркаса бассейна, следующие: ландшафтная ценность, богатый флористический состав (170 видов сосудистых растений) с редкими (Inula helenium, Leersia oryzoides, Valeriana officinalis) и охраняемыми (Althaea officinalis) видами растений.

Ядро № 3. Расположено на юго-востоке Буинского района республики Татарстан в долине р. Свияга. В границах ядра находится Государственный природный заказник регионального значения комплексного профиля «Зея буйлары».

В ландшафте территории значительные площади занимают пойменные луга, хорошо развита система стариц и озёр.

Флористическое разнообразие представлено 190 видами растений, из которых 4 вида (Bromopsis riparia,Cucubalis baccifer, Nuphar lutea, Senecio schvetzovii) нуждаются в постоянном контроле и наблюдении в природной среде, 17 - редкие и исчезающие, занесенные в Красную книгу Республики Татарстан [12].

Территория заказника в составе ядра и экологического каркаса бассейна в целом играет заметную роль в сохранении флористического, ценотического и ландшафтного разнообразия района исследования.

Ядро № 4. Включает правобережье р. Свияги в её нижнем течении, вместе с бассейнами её малых притоков - Бирли и Кубни на территории Кайбицкого и Верхнеуслонского районов Республики Татарстан. В пределах ядра насчитывается 5 памятников природы 
Фролов Д.А.

регионального значения, из которых наибольший интерес в плане флористических исследований представляют: естественный реликтовый лесной массив из дуба (памятник природы «Кайбицкие дубравы»), участок поймы рек Кубни и Свияги, озерный комплекс у пос. Новое Патрикеево Кайбицкого района Республики Татарстан. Указанные участки играют ведущую роль в сохранении ландшафтного и флористического разнообразия нижней части Свияжского бассейна, участвуют в поддержании устойчивости речного и подземного стоков.

Коридоры и буферные зоны, согласно концепции экологического каркаса, представляют собой непрерывные линейные структуры, служащие своеобразными мостами для перехода и миграции биологических видов между ядрами. Такая функция в бассейне Свияги принадлежит долинам крупных и средних рек, некрупным лесным массивам, идущим в разных направлениях преимущественно через сельскохозяйственно-освоенные территории, их роль как коридоров особенно велика на территориях с преобладанием распаханных земель. Так, в бассейне Свияги - это преимущественно сельскохозяйственные районы Ульяновский, Цильнинский (Ульяновская область) и Буинский (Республика Татарстан), в которых роль экологических коридоров играют долины малых рек - Сельдь, Бирюч, Бугурна, Цильна, Карла и их притоки. Также роль коридоров выполняют: некрупные лесные массивы, идущие в разных направлениях преимущественно через распаханные территории в Тереньгульском, Майнском (Ульяновская область), Буинском и Тетюшском районах Татарстана; пойменные луга и остепненные склоны, расположенные в центральной части Свияжского бассейна в пределах Ульяновского, Цильнинского (Ульяновская область), Буинского и Дрожжановского районов (Республики Татарстан).

Помимо ядер, коридоров и буферных зон в бассейне р. Свияги были выделены перспективные участки (в количестве 7) - резерваты редких и охраняемых видов растений. Их выделение вытекает из необходимости «усиления» экологического каркаса бассейна, путем увеличения числа охраняемых территорий. В настоящее время сеть ООПТ бассейна насчитывает 17 памятников природы ботанического профиля, 1 палеоботанический памятник общероссийского значения, комплексный государственный заказник («Зея буйлары»), а также зеленые зоны го-

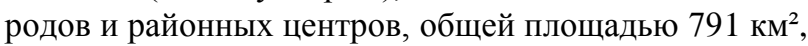
что составляет $4,3 \%$ от площади бассейна. Она охватывает чуть более половины нуждающихся в охране видов растений (117 видов; 65\%). Однако большинство экотопов этих видов часто более многочисленны на территориях, не входящих в систему ООПТ.

При реализации наших предложений по расширению сети ООПТ бассейна р. Свияги на охраняемых территориях окажется ещё 32 вида $(17,7 \%)$ из списка редких, уязвимых и подлежащих охране видов сосудистых растений. Однако следует учесть, что ещё 31 вид не попал в сеть существующих и перспективных ООПТ, поэтому работа по выявлению новых участков с раритетными видами флоры на территории бассейна будет продолжена.
Вывод

В целом современное состояние флоры бассейна p. Свияги таково, что необходимы дополнительные меры по сохранению и восстановлению её видового разнообразия.

Сохранение видов невозможно без создания эффективно организованной репрезентативной сети ООПТ в структуре экологического каркаса бассейна, где охраняемые, редкие, эндемичные и реликтовые виды растений нормально существовали бы в составе типичных растительных группировок и сообществ, сохранение которых необходимо для поддержания динамического равновесия природных экосистем. Представленный в статье экологический каркас бассейна реки Свияги создает научные предпосылки в деле сохранения флористического разнообразия региона. Выделенные ядра могут стать основой для формирования будущего экологического каркаса не только Ульяновской области и Республики Татарстан, но и сопредельных регионов, способствуя сохранению природного потенциала экологических систем Приволжской возвышенности.

\section{СПИСОК ЛИТЕРАТУРЫ:}

1. Реймерс Н.Ф. Природопользование. Словарьсправочник. М.: Наука, 1990. 638 с.

2. Бакин О.В., Рогова Т.В., Ситников А.П. Сосудистые растения Татарстана. Казань: Изд-во Казан. ун-та, 2000. 496 с.

3. Благовещенский В.В. Растительность Приволжской возвышенности в связи с её историей и рациональным использованием. Ульяновск: УлГУ, 2005. $715 \mathrm{c}$.

4. Благовещенский В.В., Раков Н.С., Шустов В.С. Редкие и исчезающие растения Ульяновской области. Саратов: Приволжское книжное издательство, 1989. $96 \mathrm{c}$.

5. Благовещенский В.В., Раков Н.С. Конспект флоры высших сосудистых растений Ульяновской области. Ульяновск, 1994. 116 с.

6. Благовещенский В.В., Раков Н.С. Реликтовые и эндемичные растения во флоре Ульяновской области // Природа Симбирского Поволжья: сб. науч. трудов. Вып. 1. Ульяновск: УлГТУ, 2000. С. 62-67.

7. Марков М.В., Папченков В.Г., Ситников А.П. Новые и редкие виды флоры Татарии // Бот. журн. 1988. Т. 73, № 1. С. 971-983.

8. Масленников А.В. Флора кальциевых ландшафтов Приволжской возвышенности. Ульяновск: УлГПУ, 2008. $136 \mathrm{c.}$

9. О государственном реестре особо охраняемых природных территорий республики Татарстан [Электронный ресурс] // Инвестиционный портал Республики Татарстан. 2009. - http://aidrt.ru/HtmlView.aspx? ItemId=66.

10. Особо охраняемые природные территории Ульяновской области / под ред. В.В. Благовещенского. Ульяновск: Дом печати, 1997. 184 с.

11. Флора и растительность Татарской АССР: Указатель литературы XVIII в. 1967 г. / под ред. М.В. Маркова и В.В. Туганаева. Казань: Изд-во Казан. ун-та, 1971. 120 с.

12. Красная книга Республики Татарстан (животные, растения, грибы). Издание второе. Казань: Издво «Идель-Пресс», 2006. 832 с. 
13. Красная книга Российской Федерации (растения и грибы). М.: Товарищество научных изданий KMK, 2008. $855 \mathrm{c}$.

14. Красная книга Ульяновской области. Ульяновск: Издательство «Артишок», 2008. 508 с.

15. Фролов Д.А. Итоги изучения урбанофлоры бассейна реки Свияги города Ульяновска // Современные проблемы морфологии и репродуктивной биологии семенных растений: мат-лы междунар. конф., посв. памяти Р.Е. Левиной (Ульяновск, 1416 октября 2008 г.): сб. научных тр. Ульяновск, 2008. C. $320-327$.

16. Фролов Д.А. Редкие и подлежащие охране виды флоры бассейна реки Свияги // Естественные и технические науки. 2010. № 1. С. 82-84.

17. Фролов Д.А. Современная флора верхнего и среднего течения бассейна реки Свияги и тенденции её развития // Биоразнообразие: проблемы и перспективы сохранения: мат-лы междунар. науч. конф., посв. 135-летию со дня рождения И.И. Спрыгина (Пенза, 13-16 мая 2008 г.): сб. науч. тр. Пенза, 2008. Ч. I. C. $328-333$.

18. Фролов Д.А. Современное состояние и проблемы сохранения биоразнообразия в системе особо охраняемых природных территорий бассейна реки Свияги // Изучение и охрана флоры Средней России: мат-лы VII науч. совещ. по флоре Средней России (Курск, 29-30 января 2011 г.) / под ред. В.С. Нови-

\section{STRUCTURE OF THE ECOLOGICAL FRAMEWORK OF THE SVIYAGA RIVER BASIN}

(C) 2017

Frolov Daniil Anatolievich, candidate of biological sciences,

associate professor of Biology and Chemistry Department

Ulyanovsk State Pedagogical University (Ulyanovsk, Russian Federation)

Abstract. In the following paper the author considers his own ecological framework of the Sviyaga River basin (the right tributary of the Volga River), which was created on the basis of a long-term study of the flora of vascular plants of a natural nature department located in the central part of the Volga Upland. The floristic and geobotanical description of the key areas - the nuclei in the structure of the river basin framework is given, with the justification of the reasons for their isolation and reduction of the rare species of vascular plants of the basin flora that betray the significance of the study area. The author briefly describes corridors and buffer zones in the structure of the ecological framework; they represent continuous linear structures and serve as a kind of bridge for the migration of biological species between the core nuclei. In addition to the cores, corridors and buffer zones in the basin of the Sviyaga River the author identified promising areas (in the number of 7) - reserves of rare and protected plant species. The paper provides information on the existing system of protected areas of the research and perspective sites recommended for inclusion in the network of existing protected areas of the Ulyanovsk Region and the Republic of Tatarstan, in order to preserve the floristic diversity of the region. The presented ecological framework will create good prerequisites for preserving of the biodiversity of the region and contributes to maintaining of the natural potential of the Sviyaga River basin.

Keywords: ecological framework; river basin; Sviyaga river; core; corridor; buffer zone; flora; vegetation; specially protected natural areas (PAS); species diversity; biodiversity; Red Book; nature sanctuary; hunting reserve; Ulyanovsk Region; Republic of Tatarstan.

УДК 574.52

Статья поступила в редакцию 25.07.2017

\title{
ЛИЧИНКИ ОТРЯДА ЕРНЕМЕRОРТЕRА КАК БИОИНДИКАТОРЫ КАЧЕСТВА ВОДЫ РЕК ЮЖНОГО УРАЛА
}

(C) 2017

\author{
Чаус Борис Юрьевич, кандидат биологических наук, доцент кафедры биологии \\ Стерлитамакский филиал Башкирского государственного университета \\ (2. Стерлитамак, Республика Башкортостан, Российская Федерация)
}

Аннотащия. В статье приводится анализ возможности использования личинок поденок отряда Ephemeroptera для повышения значимости биоиндикационных исследований в ходе экологического мониторинга рек Южного Урала. Сбор и анализ постоянства видов (в долях единицы) личинок поденок проводился в районах 